Research Article

\title{
A Study to Assess the Effectiveness of Structured Teaching Programme on Knowledge regarding Occupational Health Hazards among Factory Workers in Selected Factory of Indore, M. P., India
}

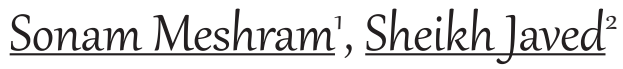 \\ ${ }^{1}$ Nursing Sister, Civil Hospital, Nagda, Ujjain, M.P., India. \\ ${ }^{2}$ Associate Professor and HOD, Community Index Nursing College, Indore, M.P., India. \\ DOI: https://doi.org/10.24321/2455.9199.202001
}

\section{I $\quad \mathbf{N} \quad \mathbf{F} \quad \mathbf{O}$}

Corresponding Author:

Sonam Meshram, Civil Hospital, Nagda, Ujjain, M.P., India.

E-mail Id:

snm.meshram.sm@gmail.com

Orcid Id:

https://orcid.org/0000-0002-8045-5085

How to cite this article:

Meshram S, Javed S. A Study to Assess the Effectiveness of Structured Teaching Programme on Knowledge regarding Occupational Health Hazards among Factory Workers in Selected Factory of Indore, M. P., India. Int J HealthCare Edu \& Med Inform 2020; 7(1\&2): 1-9.

Date of Submission: 2020-09-10

Date of Acceptance: 2020-10-01

\section{$\begin{array}{llllllll}\mathbf{A} & \mathbf{B} & \mathbf{S} & \mathbf{T} & \mathbf{R} & \mathbf{A} & \mathbf{C} & \mathbf{T}\end{array}$}

Background: Factory workers are vulnerable to various diseases and accidents are common in factories. They do not have much knowledge on the various occupational health hazards and the way to preventing it.

Methodology: Structured teaching programme followed by administration of structured knowledge questionnaire was used as an appropriate and effective method to evaluate the knowledge and attitude of factory workers regarding occupational health hazards. Ethical approval and patient consent was taken. The tool was found to be statistically reliable for the main study.

Result: A significant improvement was seen in post-test average knowledge score of the workers after administration of structured teaching programme.

Conclusion: The pre-test findings showed that knowledge of factory workers regarding occupational health hazards was inadequate. The structured teaching programme proved to be a very effective method of transforming information.

Keywords: Structured Teaching, Programmex, Occupational Health Hazardsx, Knowledge Scorex

\section{Introduction}

Historically, the term health means the condition of being 'safe and sound' or 'whole.' To a lay person, health is freedom from pain, illness and disabilities. Even in present time, many people still believe in the same concept of health. There is change in this belief in the developed world and also in the developed areas of developing countries because of research and life experiences. ${ }^{1}$ The World Health Organization (WHO) defines occupational health as a multidisciplinary activity aimed at "the protection and promotion of the health of workers, by preventing and controlling occupational hazards and accidents and by eliminating the occupational factors and conditions hazardous to health and safety at work." ${ }^{2}$ 
Factory workers face peculiar hazards in the workplace. ${ }^{3,4}$ Health issues are the most significant among the vulnerabilities experienced by the workers during their working tenure in the Readymade Garment (RMG) sector. ${ }^{6}$ The employees of this industry hardly ever benefit from occupational health-and-safety provisions. As a result their health suffers. Studies show that musculoskeletal problems, diseases of the respiratory system and eye, accidents, injuries, skin diseases, stress, insomnia, etc. are all common among these workers. The ill health is compounded by various socioeconomic factors such as poverty, lack of education, poor working conditions, excess working hours, and poor diet. ${ }^{7}$

From investigator's experience in the accidental emergency department, she has identified that most of patients reported to the casualty with complaint of cut injuries and fractures. This increased incidence of injuries occurred due to occupational health hazards. When the investigator interviewed these patients she observed that they do not have much knowledge on the various occupational health hazards and the way to preventing it.

This experience of the investigator and the fact that this topic has been understudied has interested the researcher to do a study to identify occupational health hazards, particularly among people working in the garment industry. It is important that more and more research be conducted on the health and safety issues of factory workers in order to identify the associated hazards and find ways to reduce risks. The failure to identify and solve the health and safety issues of workers has potentially serious consequences for the health and well-being of workers and their families.

\section{Operational Definitions}

Assess: It refers to an activity to estimate the knowledge and attitude regarding occupational health hazards before and after the STP as revealed by suitable knowledge questionnaire and attitude scale.

Effectiveness: Refers to the extent to which the structured teaching programme on occupational health hazards has achieved the desired effect in improving the knowledge of factory workers as assessed by structured questionnaire.

Structured Teaching Programme: Refers to systematically planned group instructions by lecture cum discussion method designed to provide information occupational health hazards among factory workers.

Knowledge: It refers to the understanding and awareness of occupational health hazards as measured by score obtained according to the items on the structured knowledge questionnaire.

Attitude: In this study, Attitude refers to the expressed belief and feeling of selected occupational health hazards among factory workers.
Occupational Hazards: In this study it refers to the undesirable effects of non-conductive occupational environment manifested in the form of physical, chemical, biological, mechanical and psychosocial hazards.

Factory Workers: In this study it refers to the male and female workers who are employed in factories.

\section{Methodology}

In view of the nature of the problem selected for the study, an evaluative approach and quasi-experimental one group pre-test post-test design without control group was found appropriate. A structured questionnaire was administered to workers working in factory. Post-test was conducted on day 7 to assess the effectiveness of structured teaching programme. Simple random sampling technique was used to select 50 factory workers working in factory as the sample for the present study.

\section{Ethical Approval}

Before conducting this study, approval was taken from authorized body of factory in Indore (M.P.). A consent was also signed by participants. Confidentiality was maintained by assigning code to each subject.

\section{Inclusion Criteria}

- $\quad$ Factory workers willing to participate in the research study

- Factory workers who are employed at various industries of Indore

\section{Exclusion Criteria}

- Factory workers outside Indore

- Factory workers those who are not willing to participate

- $\quad$ Office staff rather than factory workers

\section{Selection and Development of the Tool}

Structured teaching programme followed by administration of structured knowledge questionnaire was used as an appropriate and effective method to evaluate the knowledge and attitude of factory workers regarding occupational health hazards. The knowledge regarding occupational health hazards was measured in terms of knowledge score. Each correct answer was given a score of one mark and wrong answer or unanswered was given a score of zero. The maximum score was 27 . To interpret level of knowledge the scores were distributed as follows:

- Inadequate knowledge $\leq 50 \%$

- Moderately adequate knowledge $51-75 \%$

- Adequate knowledge $>75 \%$

The method adapted for the present study was split-half method to measure the homogeneity of the tool. The questionnaire was first divided into two equivalent levels and correlation for the half test was found using Karl Pearson's 
correlation coefficient formula. The tool was found to be statistically reliable for the main study.

\section{Result}

Table 1, shows the demographic variables of factory workers under study. Most workers had urban dwelling and nuclear family.

\section{Demographical Profile $(\mathbf{N}=\mathbf{5 0})$}

Table I.Demographical variables of the respondent $(\mathbf{N}=\mathbf{5 0})$

\begin{tabular}{|c|c|c|c|}
\hline \multicolumn{2}{|c|}{ Demographical variables } & \multirow{2}{*}{$\begin{array}{c}\begin{array}{c}\text { No. of } \\
\text { factory }\end{array} \\
\text { workers }\end{array}$} & \multirow{2}{*}{$\begin{array}{c}\text { Percentage } \\
26 \% \\
\end{array}$} \\
\hline \multirow{3}{*}{ Age } & $18-22$ years & & \\
\hline & $23-27$ years & 22 & $44 \%$ \\
\hline & $\begin{array}{l}27 \text { and } \\
\text { above }\end{array}$ & 15 & $30 \%$ \\
\hline \multirow{2}{*}{ Gender } & Male & 32 & $68 \%$ \\
\hline & Female & 18 & $36 \%$ \\
\hline \multirow{4}{*}{ Religion } & Hindu & 27 & $54 \%$ \\
\hline & Muslim & 10 & $20 \%$ \\
\hline & Christian & 8 & $16 \%$ \\
\hline & Other & 5 & $10 \%$ \\
\hline \multirow{5}{*}{ Qualification } & Illiterate & 3 & $6 \%$ \\
\hline & High school & 12 & $24 \%$ \\
\hline & $\begin{array}{c}\text { Higher } \\
\text { secondary } \\
\text { school }\end{array}$ & 12 & $24 \%$ \\
\hline & Graduation & 19 & $38 \%$ \\
\hline & $\begin{array}{c}\text { Post- } \\
\text { graduation }\end{array}$ & 4 & $8 \%$ \\
\hline \multirow{2}{*}{$\begin{array}{l}\text { Place of } \\
\text { living }\end{array}$} & Urban & 34 & $68 \%$ \\
\hline & Rural & 16 & $32 \%$ \\
\hline \multirow{4}{*}{$\begin{array}{c}\text { Year of } \\
\text { Experience }\end{array}$} & $1-3$ years & 11 & $22 \%$ \\
\hline & 3-5 years & 14 & $28 \%$ \\
\hline & 5-7 years & 15 & $30 \%$ \\
\hline & $\begin{array}{c}\text { Above } 7 \\
\text { years }\end{array}$ & 10 & $2 \%$ \\
\hline \multirow{4}{*}{$\begin{array}{c}\text { Source of } \\
\text { Information }\end{array}$} & News paper & 14 & $28 \%$ \\
\hline & Magazine & 11 & $22 \%$ \\
\hline & Internet & 18 & $3 \%$ \\
\hline & $\begin{array}{l}\text { In-service } \\
\text { education }\end{array}$ & 07 & $14 \%$ \\
\hline \multirow{2}{*}{$\begin{array}{l}\text { Type of } \\
\text { family }\end{array}$} & Nuclear family & 36 & $72 \%$ \\
\hline & Joint family & 14 & $28 \%$ \\
\hline
\end{tabular}

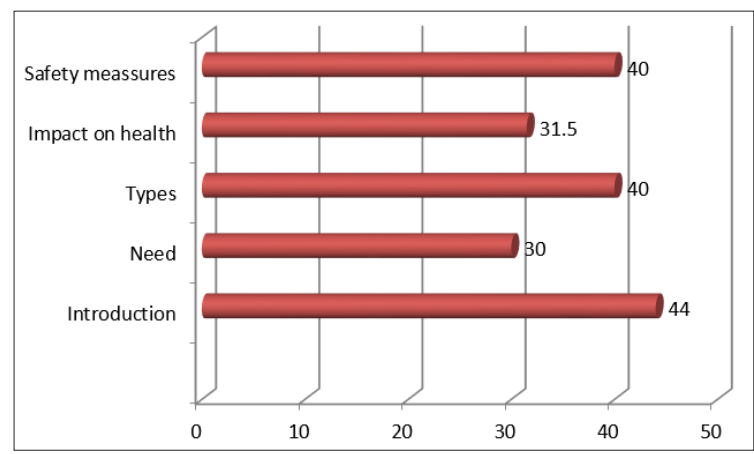

Figure I.Pre-test Knowledge Scores of Factory Workers Regarding Occupational Health Hazards

Fidure 1, shows pre-test knowledge scores of the workers. Pre-test knowledge of the subjects was found to be below 50 in regard to safety measures. There was a marked improvement in post-test knowledge scores (Table 2).

Table 2.Post test knowledge score of factory workers regarding occupational health hazards

\begin{tabular}{|c|c|c|c|}
\hline \multirow{2}{*}{ Area of knowledge } & \multicolumn{3}{|c|}{ Post-test knowledge } \\
\cline { 2 - 4 } & Mean score & SD & Mean\% \\
\hline Introduction & 2.32 & 0.71 & 77.33 \\
\hline Need & 3.45 & 0.61 & 88.5 \\
\hline Types & 2.56 & 0.50 & 88.53 \\
\hline Impact on health & 3.52 & 0.54 & 88 \\
\hline Safety measures & 3.40 & 0.64 & 85 \\
\hline
\end{tabular}

Table 3.Comparison of Average Knowledge Score before and after Administration of Structured Teaching Programme

\begin{tabular}{|c|c|c|c|c|c|}
\hline $\begin{array}{c}\text { Know- } \\
\text { ledge }\end{array}$ & $\begin{array}{c}\text { No. of } \\
\text { factory } \\
\text { workers }\end{array}$ & $\begin{array}{c}\text { Pre- } \\
\text { test } \\
\text { mean } \\
\text { score }\end{array}$ & $\begin{array}{c}\text { Post- } \\
\text { test } \\
\text { mean } \\
\text { score }\end{array}$ & $\begin{array}{c}\text { Mean } \\
\text { of diffe- } \\
\text { rence }\end{array}$ & $\begin{array}{c}\text { Paired } \\
\mathbf{t}=\text { test }\end{array}$ \\
\hline $\begin{array}{c}\text { Overall } \\
\text { know- } \\
\text { ledge } \\
\text { score }\end{array}$ & 50 & 6.58 & 15.34 & $\begin{array}{c}8.76 \\
(\mathrm{SD}=1.9)\end{array}$ & $\mathrm{T}=32.58$ \\
\hline
\end{tabular}

$\mathrm{HS}, \mathrm{p}-0.000, \mathrm{df}=49$

Table 4.Determination of Overall Mean Knowledge Score before and after Structured Teaching Programme $\mathbf{N}=\mathbf{5 0}$

\begin{tabular}{|c|c|c|c|}
\hline $\begin{array}{c}\text { Area of } \\
\text { knowledge }\end{array}$ & $\begin{array}{c}\text { Pre-test } \\
\%\end{array}$ & $\begin{array}{c}\text { Post- } \\
\text { test \% }\end{array}$ & $\begin{array}{c}\% \\
\text { Enhancement }\end{array}$ \\
\hline Introduction & 44 & 77.33 & $33.33 \%$ \\
\hline Need & 30 & 88.5 & 58.55 \\
\hline Types & 40 & 85.33 & $45.33 \%$ \\
\hline Empact & 31.5 & 88 & $56.5 \%$ \\
\hline Safety measure & 40 & 85 & $45 \%$ \\
\hline
\end{tabular}


Tables 3 and 4 show that that the structured teaching programme effectively improved among subjects the knowledge regarding occupational health hazards.

\section{Discussion}

The key finding of the current study was that the structured teaching programme improved the knowledge of factory workers regarding occupational health hazards and safety. A study by Mersal in Cairo showed that the structured teaching program improves the knowledge and practice of workers regarding occupational hazards. ${ }^{8}$ National institute of health and family welfare in 2002 conducted a study to assess the level of knowledge of sedentary workers regarding occupational diseases. Hence, distribution of information booklet was found to be effective in assessing the knowledge of sedentary workers regarding occupational lung diseases. ${ }^{9}$ Similarly, Zwerling in a study concluded that improving work environment and promoting safety education among workers is necessary. ${ }^{10}$

\section{Conclusion}

The main aim of the study was to assess the effectiveness of structured teaching programme on knowledge regarding occupational health hazards among factory workers. The pre-test findings showed that knowledge of factory workers regarding occupational health hazards was inadequate. The administration of structured teaching programme helped the workers to understand more about occupational health hazards. Most of the workers were having adequate level of knowledge after the teaching programme. The structured teaching programme proved to be a very effective method of transforming information.

On the basis of the findings, the study can be replicated on a large scale to generalize the findings.

\section{Conflict of Interest: None}

\section{References}

1. Kumar R. Indian Journal of Community Medicine. Official publication of Indian association of preventive and social medicine 2006; 31(2): 92.

2. https://www.who.int/occupational_health/ publications/globstrategy/en/index5.html. Accessed 24.09.2020.

3. Brown GD. Effective protection of workers' health and safety in global supply chains. Int J Labour Res 2015; 7(1/2): 35-53. [Google Scholar].

4. English B. Global women's work: historical perspectives on the textile and garment industries. J Int Aff 2013; 1: 67-82. [Google Scholar].

5. https://www.ibef.org/pages/37923. Accessed 25.09.2020.

6. Kabir H, Maple M, Usher K, Islam MS. Health vulnerabilities of Readymade Garment (RMG) workers: a systematic review. BMC Public Health 2019; 19: 70. Published online 2019 Jan 15. DOI: 10.1186/s12889019-6388-y.

7. Saha TK, Dasgupta A, Butt A, Chattopadhyay O. Health Status of Workers Engaged in the Small-scale Garment Industry: How Healthy are They? Indian J Community Med 2010; 35(1): 179-182. DOI: 10.4103/09700218.62584. PMID: 20606949; PMCID: PMC2888354.

8. Mersal FA and Esmat OM. Structured Teaching Program on Occupational Health Hazards among Painting Workers at Elherafeyien City in Cairo. Biomedicine and Nursing 2018; 4(3): 1-11.

9. National institute of health and family welfare. 2002. National programme for control and treatment of occupational lung diseases. From www.nihfw, org/ ND/ (Accessed: 28.09.2020).

10. Craig Z. Injuries among construction workers in rural lowa: Emergency department surveillance. Journal of occupational and environmental Medicine 1996; 38(7): 698-704. 


\section{Appendix}

\section{Structured Knowledge Questionnaire}

\section{Section A: Socio-Demographic Data}

Instructions: Please read the following question and place a tick $(\checkmark)$ mark in the appropriate box given below kindly ensure that you do not miss any item. The information given by you will be kept confidential.

1. Age in year
a) $18-22$
b) $\quad 23-27$
c) 28 and above

2. Gender

a. Male

b. Female

3. Religion

a. Hindu

b. Muslim

c. Christian

d. Other

4. Basic Educational Information

a. High school

b. Higher secondary

c. Graduated

d. Post - graduated

e. Illiterate

5. Medium of Instruction in Basic Education

a. English

b. Regional language

6. Place of Living

a. Urban

b. Rural

7. Years of Experience

a) 1-3 years

b) 3- 5 years

c) $5-7$ years

d) 7 and above

8. Source of Information about Occupational Health Hazard

a) News paper

b) Magazine

c) Internet

d) In-service education

9 Types of family

a) Nuclear family

b) Joint family

c) Absence of illness 


\section{Section B}

A. Introduction

1. Health is

a) Absence of illness

b) Health means not seeing a doctor

c) Presence of illness

d) Absence of stress

2. Probability of the event that might occur Severity of the event if it occurs

a) Accident

b) Hazard

c) Risk

d) None of the above

3. Bhopal gas tragedy happened in

a) 3 December 1984

b) 3 November 1984

c) 3 August 1984

d) 3 January 1984

4. Occupational health means

a) Health safety in road

b) Health safety in home

c) Health safety in work place

d) Health safety in play ground

5. What is hazard

a) A hazard is anything with the potential to cause harm

b) A hazard is anything with the potential to cause accident

c) A hazard is anything with the potential to cause risk

d) None of above

6. Occupational health hazards is

a) Hazard experience in home

b) Hazard experience in workplace

c) Hazard experience in outside

d) Hazard experience in market

B. Need

7. Need for occupational health

a) Promoting work wellbeing

b) Providing high salary

c) Reducing working time

d) Providing a poor working atmosphere

8. Occupational health is essential for

a) Reducing working hours

b) Increase health hazards

c) Maintain and promotion of workers health

d) Promotion of risk

9. Good occupational health

a) Reduce sick leave 

b) Increase sick leave
c) Provide sick leave
d) None of them

10. The main goal of occupational health
a) To reduce occupational accident
b) To provide more leave
c) To provide less working hours
d) To reduce holiday
C. Types

11. Causes of occupational hazards
a) Air
b) Water
c) Noise
d) All of the above

12. Which one is not type of occupational health hazard
a) Physical hazard
b) Biological hazard
c) Psychological hazard
d) Social hazard

13. Physical hazard exclude
a) Noise
b) Radiation
c) Vibration
d) crowd

14. Physical hazard include
a) Environmental hazard
b) Ergonomic hazards
c) Biological hazard
d) Psychological hazard

15. Causes of physical health is
a) Machine
b) Detergent
c) Mental stress
d) Insect
D. Impact

16. Disease spread by occupational hazard
a) HIV
b) Malaria
c) Cancer
d) Jaundice

17. Physical hazard is
a) Hearing loss
b) Dermatitis
c) Heart attack
d) Hepatitis 
18. Light can cause
a) Occupational deafness
b) Occupational cancer
c) Occupational cataract
d) Occupation arthritis

19. Radiation can cause
a) Pneumonia
b) Cancer
c) Fracture
d) Cataract

\section{Noise can cause}
a) Occupational cataract
b) Occupational pneumonia
c) Occupational deafness
d) Occupational blindness

21. Cold can cause
a) Hypotension
b) Hypo pyrexia
c) Hypertension
d) Hyperpyrexia
E. Saftey Messure

22. Personal protective equipment use in factory are
a) Mask, gloves, shoes, goggles, gowns
b) Sun glasses, boots, cap
c) Scissor, knife, needle
d) Hammer, weight machine, stick

23. The ways to make a situation safer
a) Increase the risk
b) Reduce the risk
c) Increase the causing agent
d) Increase the working efficiency

24. Workplace related injuries, illnesses and deaths impose costs upon?
a) Employers
b) Employees
c) The community
d) The country.

25. What is the medical emergency telephone number in India
a) 105
b) 106
c) 107
d) 108

26. World Day for Safety and Health is celebrate on
a) April 28
b) April 29
c) April 18
d) April 18 
27. Purpose of the Workplace Safety and Health Act is

a) To protect worker safety and health in the workplace

b) To increase risk in work place

c) To educate the worker

d) To provide financial support for workers 